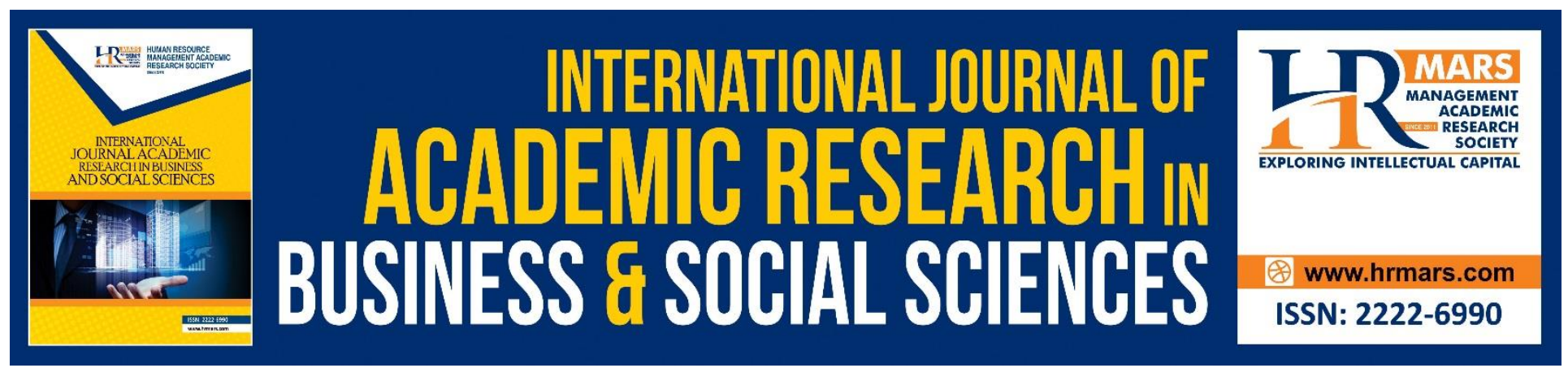

\title{
The Identity of Women according to the Thinking of Said Nursi
}

Mohamad Zaidin Mohamad, Nurfatin Izati Mohamad Amin, Najmiah Omar, Siti Khatijah Ismail, Sofyuddin Yusof, Ahmad Fauzi Hasan, Roslan Abdul Rahman

To Link this Article: http://dx.doi.org/10.6007/IJARBSS/v9-i3/5716 DOI: $10.6007 /$ IJARBSS/v9-i3/5716

Received: 02 Feb 2019, Revised: 17 Feb 2019, Accepted: 30 Feb 2019

Published Online: 03 March 2019

In-Text Citation: (Mohamad et al., 2019)

To Cite this Article: Mohamad, M. Z., Amin, N. I. M., Omar, N., Siti Khatijah Ismail, Yusof, S., Hasan, A. F., \& Rahman, R. A. (2019). The Identity of Women according to the Thinking of Said Nursi. International Journal of Academic Research in Business and Social Sciences, 9(3), 555-564.

Copyright: (C) 2019 The Author(s)

Published by Human Resource Management Academic Research Society (www.hrmars.com)

This article is published under the Creative Commons Attribution (CC BY 4.0) license. Anyone may reproduce, distribute, translate and create derivative works of this article (for both commercial and non-commercial purposes), subject to full attribution to the original publication and authors. The full terms of this license may be seen

at: http://creativecommons.org/licences/by/4.0/legalcode

Vol. 9, No. 3, 2019, Pg. 555 - 564

http://hrmars.com/index.php/pages/detail/IJARBSS

JOURNAL HOMEPAGE

Full Terms \& Conditions of access and use can be found at http://hrmars.com/index.php/pages/detail/publication-ethics 


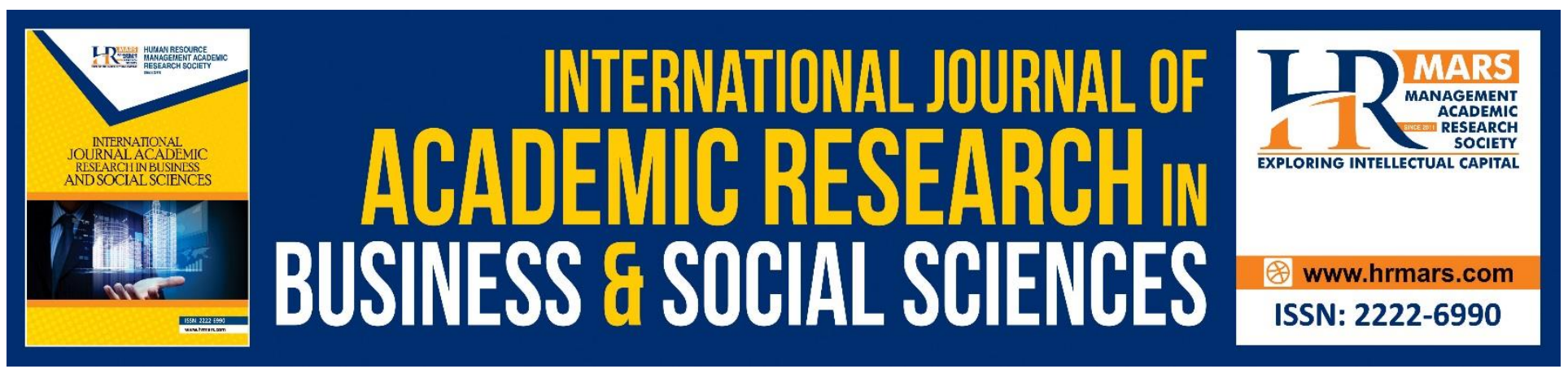

\title{
The Identity of Women according to the Thinking of Said Nursi
}

\author{
Mohamad Zaidin Mohamad, Nurfatin Izati Mohamad Amin, Najmiah \\ Omar, Siti Khatijah Ismail, Sofyuddin Yusof, Ahmad Fauzi Hasan, \\ Roslan Abdul Rahman \\ Universiti Sultan Zainal Abidin
}

\begin{abstract}
The role of women in creating a dynamic Islamic society is not necessarily disputed. However, in today's modern era, women have to face various challenges and constraints. This study aims to identify Nursi's thoughts on the issue of Islamic women. This study is qualitative by using the content analysis approach on the book of Murshid Akhawat al-Akhirah. The study found there are three aspects of the discussions above show Nursi's concern about women. Women are the pillar of success in the family institution. Without a successful family institution, a nation would face various forms of misfortune and turbulence. Therefore, the issue of marriage, aurat and hijab, as discussed by Nursi, should receive attention from all parties.
\end{abstract}

\section{INTRODUCTION}

The global Islamic community has generally viewed the question of Islamic identity very seriously after the globalization era emerged. This is one term that has been mentioned since the mid-1980s and became popular in the 1990s. According to al- Ani (2009), two main factors have become the basis for this situation, namely the feeling of being threatened and the need to perform islah and reformation. In the current situation, the need is rather based on global developments and changes related to political, economic, social, technological, environmental and other aspects.

The global Islamic community, specifically in Malaysia, cannot remain docile but must participate together with the global community to draw up changes to their lives in tandem with the current tide of global developments. Hence, these changes, including the performance of islah, must adhere to the Syariah and not deviate from the demands and guidelines of Islam. Herewith lies the significance of Islamic identity. Thus, without a strong identity, Muslims would be swept away by current ideologies that are inconsistent with Islamic civilisation as well as historical or cultural values (Imarah, 2004). 


\section{THE BOOK OF MURSHID AKHAWWAT AL-AKHIRAH}

The Book of Murshid Akhawwat al-Akhirah is part of the dimensions of Nursi's thinking about women. Two aspects that were given special attention to this timid and bashful group was their humble and compassionate character. Both these characteristics are part of a woman's instincts that can only be supported by religious education (tarbiyah agama). This article focuses on three aspects, namely issues pertaining to marriage, the aurat and hijab. This is because these issues have not received the proper attention by women, families or society, who are responsible for propagating social ills related to women. It can be concluded that when discussing solutions for overcoming social ills, the religious aspect cannot be discounted (Hazizan et. al, 2003; Altwaijri, 2014; Khairuldin et al, 2018)

Since one of the four fundamentals of Risalah an-Nur is compassion and women are champions of compassion and love that even the timidest among them would be willing to sacrifice their life to save their children. Humble children and women face a daunting situation now and this brings forth Nursi's sense of responsibility to explain to them the elements of a woman's instinct, especially the unmarried female students in Risalah an-Nur. Nevertheless, he felt that this situation should not be widely publicised because this is a special case where some wish or are forced to carry on living an unmarried or single life.

Hence, since the significance of providing an understanding is a big task before any action can be taken, Nursi decided to explain this to his students. He said that the current situation was not like previous eras. In about half a century, a new education system in Europe was established to replace Islamic education. What he meant was that people were getting married because according to Islamic teachings by doing so one could abstain from committing sins; while Western education saw marriage as placing a wife under the command and control of the husband who loves the wife only when she is young and then later on, inconvenience and burden her beyond the normal hours of the day. Misfortune would build if she finds that he is incompatible in terms of syarak or not in an equal standing with her when rights according to syarak are not fulfilled. Nursi emphasised that the three factors lead to marriage are:

First: The wisdom of Allah SWT who has emplaced in humans the urge and need to propagate one's progeny. However, women are advised not to marry just because of their feelings or instincts.

Second: A woman's instinct dictates that she needs someone who can help her manage her life because women are naturally timid. Hence, it might be better for them to earn a living, like that of women in villages, whereby these women are much better off instead of condescending to their husbands who lack Islamic education. Thus, Said Nursi advised women, especially his students, to seek husbands who are steadfast in prayer, of good character and are honest in loving their wives.

Third: A woman's instinct is to love her children and enjoy spending time with them. Here, the natural inclination to marry is further supported by the children's caregiving for the mother, the act of intercession on behalf of the mother and offering prayers for the mother after her death (Nursi, 2014).

Based on this, Nursi had advised his students who were unmarried not to 'sell' themselves or give themselves away cheaply by exposing their aurat if they have not met their ultimate choice 
(mukmin) who is pious (soleh) and possesses a good character compatible with theirs. Moreover, they must remain unmarried if they have not met a man who is suitable and compatible ( $k u f u$ or kafa'ah). This was like what some students from Risalah an-Nur had done, whereby they waited until someone suitable, knowledgeable in Islam and from an Islamic tarbiah as well as having the enthusiasm to become a life partner came along so that eternal happiness was not jeopardised by merely enjoying earthly pleasures of life. Thus, although the word kafa'ah or kufu is discussed in various dimensions by ulama', however, the emphasis is on the religious and morality aspects (Royani, 2013).

Hence, mothers should continuously nurture and care for their children because it is an instinct implanted in their human souls as compared to animals. In a similar vein, it was the wisdom of Allah SWT that had implanted in men the instinct of humbleness and jealousy so that they could help timid-natured mothers and helpless children.

\section{MARRIAGE}

Someone had written a letter to Nursi about the issue of being unmarried, whereby he felt that Nursi had encouraged his students to live an unmarried life although this advice contradicted the sunnah of the Prophet SAW. This was conveyed by a student to Nursi who was at time critically ill. Nevertheless, he was still able to respond to that statement by giving three views about the statement.

First, Nursi stated that when efforts to repel the terrible attacks of atheist beliefs for the past forty years had made Muslims sacrifice everything they had, he decided to sacrifice for the truth of the alQuran. This was also because he had served the al-Quran is the best way with all his sincerity; thus, he felt he should leave the world of marriage, which was temporary in nature, although he knew it as a sunnah of the Prophet SAW (Nursi, 2014).

According to Nursi, some ulama' who had experienced misfortunes had issued a fawta that favoured elements of bid'ah or had pretended to support them because of the hardship faced by their children and families. Hence, this situation requires a high level of sacrifice, a firm determination as well as not depending on humans or other things to fend off vicious attacks on religion. Therefore, he abstained from marriage although he knew it was the sunnah of the Prophet SAW so that he would avoid the prohibited elements (haram) and be able to perform the mandatory practices as well as fulfil the demands of Islam. He also said that he might not be able to commit what is prohibited in order to perform one act according to the sunnah of the Prophet SAW. Nursi added that there are ulama' who practice the sunnah and yet found themselves committing major sins, what is prohibited or abstaining from a large number of practices that are sunnah and elements of fardhu for the past forty years.

Second, there are verses of the al-Quran that portray humility, such as verse 3 in surah al-Nisa' and several hadith that encourage marriage and similar activities, which are in the form of a command. In this context, Nursi said: 
INTERNATIONAL JOURNAL OF ACADEMIC RESEARCH IN BUSINESS AND SOCIAL SCIENCES

Vol. 9, No. 3, March, 2019, E-ISSN: 222 2-6990 (C) 2019 HRMARS

It is not a compulsory or permanent command, but it is a sunnah (sunnah muakkadah) that is very much encouraged and subject to certain conditions and sometimes these conditions are always not available to everyone.

He then mentioned about hadith that do not portray the values of priesthood (celibacy) in Islam (لا رهبانية في الاسـلام). What he meant was self-isolation or living an unmarried life, like that of priests or monks, which is prohibited or rejected without any basis. This hadith encourages humans to be involved in societal life (Nursi, 2014)

Third, he never instructed his students to abstain from marriage and felt it was a personal issue; in fact, it was something that does not have to be told. However, the students themselves came from various levels and walks of life. Some among them had decided that it was mandatory not to be tied down with earthly or human needs as far as possible, at the current time, for a period in their lives in order to reach the ultimate sacrifice, a composed firmness or complete sincerity (Nursi, 2014). In fact, many students from Risalah an-Nur had married and practiced the sunnah of the Prophet SAW as best as possible. Risalah an-Nur had talked to them:

Make your home a small Madrasah al-Nur, as a place to receive knowledge and ma'rifah so that these children can grow up in surrounded by religious values, have the potential to intercede on the Day of Resurrection and be good children in this world. At that moment this noble sunnah is truly implemented in your life. This would be different if the children were educated in a western manner just like thirty years ago. Indeed, these children will not benefit you in this world from one aspect while they would allege you in the Hereafter. At that time there would be no reason to regret and it actually contravenes the wisdom of the Sunnah of the Holy Prophet itself.

\section{WOMEN'S AURAT}

The manhaj of Risalah an-Nur contains the characteristics of blessings, compassion and love. Women are famous for possessing compassion and love compared to men. However, in this issue Nursi was firm in his advice and discussions (Nursi, 2014). This shows the social upheavel caused by women influenced by the thinking and culture of foreign women. According to hadith by the Prophet SAW, the gravest slander (fitnah) at the end of the Islamic era was the slander by women. Nursi stressed that slander at the end of the Islamic era concerned women who liked to expose their aurat based on several reasons, such as not considering the boundaries of the religion or using modernization as an excuse and a civilization based on Western ideas. For example, Western media have frequently claimed that Islam is a religion that hinders progress by negatively portraying Islamic women wearing the headscarf (Nazirah and Zanariah, 2016).

In most history books it is said that was a group of women who were brave and carried weapons called Amazon Women. They even formed an army among them and went to war. Similarly, 
in the present era, the opposition shown by atheists towards Islam has seen a group that envies Islam and is on a path that follows the ammarah bissu'. They had also surrendered their leadership and its affairs to Satan, which was in the form of a group of naked women, exposing their calves as well using it as a weapon to 'wound' and 'stab' the faithful. Hence, they had closed the door to marriage and opened the door to "murder" by influencing the heart and soul to commit major sins.

According to Nursi, it is a fair retribution when their legs are hampered with slander (fitnah) that fuels (wood) the fires of hell as they would be the first to burn in hell. This is because they had exposed their calves for years in front of men who were not their mahram.

Besides that, Nursi also said that they have lost a suitable spouse, thus, they were unsuccessful in securing a husband when instinctively and naturally they need a husband. This is because they had wasted their trust and allegiance in this world. Moreover, they have reached a point where they are eventually neglected and have lost their significance and protection. This is the effect of wanting a marriage but not safeguarding the rights of the marriage.

Hence, a beautiful woman must use her beauty according to the syariat so that her temporary state of beauty would become eternal beauty, whose rewards and enjoyment would be attained in heaven. Otherwise, she would reel in pain and suffer in her old age (Nursi, 2014).

\section{HIJAB}

Allah SWT exhorted in verse 59 surah al-Ahzab, meaning,

"O Prophet tell your wives and your daughters and the women of the believers to bring down over themselves [part] of their outer garments. That is more suitable that they will be known and not be abused. And ever is Allah Forgiving and Merciful"

This verse instructs one to wear the hijab, however, a false sense of modernization has contradicted this divine (Rabbani) law, whereby the hijab is not seen as something instinctual for women, rather a hindrance or a restriction for them. Nursi had explained in Risalah an-Nur about the 4 wisdoms, which shows that the laws of the al-Quran are consistent with a woman's instinct and contravening it is opposing the instinct (Nursi, 2014).

\section{First Wisdom: Hijab and Safeguarding Dignity is a Woman's Instinct}

According to Nursi, verily the hijab is instinctual to a woman because a woman's instinct is filled with tenderness and timidity, hence, there exist in their souls a yearning for men who would protect them and their children, whom they care about more than themselves. They naturally like to be loved and avoid anything that distances, isolates or causes hate towards them.

Hence, instinctually they need a hijab as a precautionary measure against exposing themselves as well as avoiding any untoward acts against them. Indirectly, it distances them from negative perceptions in the eyes of the husband. Moreover, in this context, older women have to be even more conscious by wearing the hijab compared to younger women.

Since women have a 'soft' character as well as easily influenced, surely, they would shun away from distasteful views that are permitted (halal), whereby it acts as a poison. For example, many European women expose their aurat and like to groom themselves as well as complain that men are staring at them. These actions unconsciously invite danger onto themselves. Khan (2013) found that wearing the hijab can control people looking or staring at them, especially men looking at women. 
Therefore, the hijab is a factor that influences the positive communicative concentration between men and women.

They actually do not realise that ignorant modernization has destroyed as well as opened the path to adornment that contradicts human instinct. The al-Quran has instructed one to wear the hijab and besides being an instinct, it is able to protect women from humiliation and destruction that is caused by the vileness as well as a lack of logic and humbleness. They are a source of love and compassion as well as a humble companion for their husbands in eternity.

According to Nursi, women carry within them the fear of men and this fear requires them to wear the hijab and not to expose their aurat. This is because the satisfaction of transgressing the syariat for about ten minutes would cause them to bear the pains of pregnancy for nine months and thereafter care for a young child for many years to come.

Hence, with this frequently happening to women, they would be naturally afraid of someone besides their spouse (mahram) as well as distance themselves, as an instinctual reaction. Their helpless situation reminds them to be always on the lookout as well as encourage them to close their aurat in order not to sexually excite those who are not their mahram, which indirectly hinders unwarranted actions towards them. Instinct teaches them that the hijab is a strong defence as well as a safe form of barrier (Nursi, 2014).

\section{Second Wisdom: A Woman is a Friend to Her Husband in this World and in the Hereafter}

Nursi stated that unconditional love between men and women is not limited for the fulfilment of earthly needs only but they would also be partners in the Hereafter. Hence, the nature of love must be continued until the end of their lives and the al-Quran taught us that the hijab, in its absolute sense, is an instinctual need, and can nurture a harmonious relationship between husband and wife. Moreover, the husband is her partner in eternity.

Verily, this strong bond and a deep feeling of love between man and woman does not arise due to the joy of solely living in this world. Women are not only a man's best friend on this earth but are eternal friends. Since the wife and husband are best friends in their married life, thus, it should not attract the attention of anyone else except the eternal partner and friend towards her beauty and it would be inappropriate to disturb her or cause her to be upset or be envious.

In addition, a pious husband has a strong faith and he does not limit his love to his wife only when living on this earth. He also does not offer an animalistic kind of love, which is restricted due to her beauty and as long as the beauty is present but rather, he pours her with sincere and permanent love regardless of her age or beauty until Jannah.

According to Nursi, this is because the wife is a partner in eternal life. Hence, a woman should focus her beauty specifically towards her husband as well as restrict her love for her husband, as demanded by human values. Syara' demands that a husband must be in kufu or kafa'ah with the woman, which means that there must be compatibility and mutual understanding. The most important elements of kufu is from the religious aspect, as mentioned earlier.

It would be sheer happiness if a husband sees the religious strength of his wife and then exemplifies it and becomes religious strong himself, thus, not losing a true and eternal friend. This 
should also serve as an example to the wife so that they both are strongly bonded with faith and piousness.

Besides that, it would be a loss for a man if he drowns in his folly that eventually causes the loss of a good and pious wife as well as a loss for the wife if she does not follow the example of a religious and pious husband. This means that one should not lose a husband or wife who is pious and good as well as capable of guiding us nearer to Allah SWT (Nursi, 2014).

\section{Third Wisdom: The Hijab Increases Trust and Love}

This wisdom proves the absolute statement about happiness in a household. A happy household would be eternal if the husband and wife have mutual trust and are loving towards one another. Neglecting the hijab would cause the loss of trust and love as well as sour the relations between husband and wife.

A human being does not instinctively possess such humbleness towards his mahram, for example a younger sister, because the bond of a mahram induces a sense of non-sexual love that exists due to familial ties. This noble relationship avoids the inclinations towards sexual tendencies, unless what is not supposed to be exposed, is then exposed, such as the calf. Besides that, these situations could raise a sense of averseness in their souls and lose the feeling of forbiddance. Since the characteristics of the mahram creates a sense of familial bond, they are forbidden and different from the rest. Hence, forbidding the exposure of a part of the body applies to the mahram as well as the non-mahram.

This is also because there are no signs that can differentiate what is actually forbidden to look at. Some of the mahram could be morally deficient and exhibit stares or looks that are sexually motivated, which could be terribly demeaning and feared by humans, especially women (Nursi, 2014).

\section{Fourth Wisdom: Unveiling the Hijab Fends off Marriage}

Verily, having a vast number of descendants is demanded from various aspects. Every race and government support this statement as mentioned by the Prophet SAW, meaning:

"Marry so that you would multiple, so that I would be proud to see so many of my followers on the day of Judgment".

It is clear that by removing the hijab and giving way to the wanton display of beauty or vanity (tabarruj) would distance oneself from marriage and decrease the amount of marriage practices. This is because a man, although he is impious (fasik) and evil, would still wish to find a life-time partner who has been brought up well and holy. They do not want a woman who lacks values and exposes her aurat. Hence, they would prefer to be unmarried, which could eventually lead to vice.

According to Nursi, a woman's duty is to manage the household and care for the children, property, the husband as well as anything related to the household. Thus, the most significant characteristic would be loyalty and trust. One's attitude of the wanton display of beauty or vanity (tabarruj) and exposing the aurat would discredit this loyalty and instigate doubt in the husband's 
trust on the wife. According to 'Atiyyah and al-Juzayri in Zawawi dan Rahman (2008), a wife's responsibility to a husband is to safeguard the husband's dignity, which is to abstain from atrocities (adultery) or actions that could be construed as a preamble to adultery, including unrestricted socialising and exposing of the aurat.

Although being courageous and benevolent are two commendable attitudes for men, however, for women it is a mazmumah characteristic because it affects trust and loyalty leading to a lack of demureness and wastage. Since the husband's role is not limited to caring for the wife's property as well as being bound to her, thus, it is not demanded for him to do what should be done to a wife. Hence, a man is not bound to only one wife but can marry other women too.

Nursi saw the danger of displaying one's beauty or vanity (tabarruj) and its effects on the Islamic world. This was because the Europeans were used to a cold and freezing weather, whereas in Asia, especially the Islamic countries, the weather is comparatively hot and humid, while the environmental effects on the human mind is quite well known.

In these cold areas as well as the people who are feeling the cold, displaying one's beauty or vanity (tabarruj) could not be sexually stimulating or excite the sexual desire that could lead to extreme actions among those who are sensitive or easily sexually stimulated. To display one's beauty or vanity (tabarruj) and not wearing the hijab could stimulate sexual desires, thus, expressing these uncontrollable sexual desires could lead to excessive behaviour that weakens them generally (Nursi, 2014).

\section{Conclusion}

The three aspects of the discussions above show Nursi's concern about women. Women are the pillar of success in the family institution. Without a successful family institution, a nation would face various forms of misfortune and turbulence. Therefore, the issue of marriage, aurat and hijab, as discussed by Nursi, should receive attention from all parties.

\section{Acknowledgement}

Special thanks to Research Management, Innovation \& Commercialization Centre (RMIC) and University Sultan Zainal Abidin (UniSZA) for funding this research.

Corresponding Author: Mohamad Zaidin Mohamad.mzaidin@unisza.edu.my

\section{References}

Khan, A.Q., Qureshi, M.N. \& Anwar, S.M. (2013). Glory of Muslim Hijab. Germany: Lambert Academic Publishing.

Royani, A. (2013). Kafa'ah dalam perkahwinan Islam. Al-Ahwal. 5(1): 103-119.

Al-'Ani, K.N.M. (2009). al-Huwayyah al-Islamiyyah fi Zaman al-`Awlamah al-Thaqafiyyah. Iraq: Markaz al-Buhuth wa al-Dirasat al-Islamiyyah.

Altwaijri, A.U. (2014). The Islamic World and Millenium Chalenges. Ribat: ISESCO.

Noon, H., Haneef, M.A.M., Abdullah, S. \& Amin, R.M. (2003). Research Notes Religiosity and Social Problems in Malaysia. Intellectual Discourse. 11(1): 77-87. 
Imarah, M. (2004). Ayyuhuma Awla: al-Huwiyyah am al-Nahdah. Jaridah al-Sharq al-Awsat. [22 Januari].

Bakar, M.Z.A. \& Abdullah, W.A.R.K.W. (2008). Hak suami isteri dalam perkahwinan Islam: analisis menurut fiqh. REKAYASA. 4: 35-52.

Lee, N. \& Noor, Z. (2016). Islam or progress of the nation?: An assessment of the aurat issue in Malay newspapers and magazines in the 1930s. Malaysian Journal of Society and Space. 12(6): 4350.

Al-Nursi, B.S. (2014). Murshid Akhawat al-Akhirah. Istanbul: Sozler Publication. 